Огляди

DOI: $10.31793 / 1680-1466.2021 .26-4.366$

\title{
Автоімунні захворювання щитоподібної залози та основні маркери їх патогенезу і діагностики
}

Т.Ф. Захарченко, В.I. Кравченко

ДУ «Інститут ендокринології та обміну речовин ім. В.П. Комісаренка НАМН України»

\begin{abstract}
Резюме. Огляд присвячено оцінці основних гуморальних факторів у патогенезі автоімунних захворювань щитоподібної залози (АЗЩЗ) та можливості їх використання при діагностиці та складанні прогнозу. Показано, що клінічно різні тиреоїдит Хашимото (ТX), хвороба Грейвса (ХГ) та офтальмопатія Грейвса (ОГ) тісно пов'язані патофізіологічно і мають подібні імуноопосередковані механізми - продукцію автоантитіл до тиреоїдних антигенів і лімфоїдну інфільтрацію тиреоїдної паренхіми. Втрата імунної толерантності до автоантигенів тиреоїдної пероксидази (thyroid peroxidase, TPO), тиреоглобуліну (thyroglobulin, Tg) та рецептору тиреотропного гормону (thyroid-stimulating hormone receptor, TSHR) $\in$ основою розвитку АЗЩЗ. Наголошується на ролі прозапальних та протизапальних цитокінів, які продукуються клітинами імунної системи та тиреоцитами. Цитокіни беруть участь в індукторній та ефекторній фазі імунної відповіді та запалення, відіграючи ключову роль у патогенезі АЗЩЗ. Значний вплив на розвиток і прогресування АЗЩЗ має дисбаланс між Th17лімфоцитами, які підтримують автоімунну відповідь, та регуляторними Т-клітинами (regulatory $T$ cells, Treg), які пригнічують автоімунний процес. Недостатність регуляторних В-клітин (regulatory B cells, Breg) та Treg, які виробляють протизапальні цитокіни, порушує імунологічну толерантність і викликає аномальну продукцію прозапальних цитокінів, відіграє певну роль у патогенезі АЗЩЗ. Виявлення імунних клітин та антитиреоїдних антитіл у тканині щитоподібної залози (ЩЗ) та визначення рівнів прозапальних та протизапальних цитокінів у сироватці крові можуть дати інформацію про їх участь у патогенезі АЗЩЗ та можуть служити маркерами активності захворювання. Розглянуто діагностичне значення рівня цитокінів, тиреоїдних автоантитіл при ТХ, ХГ і ОГ та їх здатність відображати наявність та активність захворювання.
\end{abstract}

Ключові слова: автоімунні захворювання щитоподібної залози, тиреоїдит Хашимото, хвороба Грейвса, офтальмопатія Грейвса, Th17-лімфоцити, Treg, Breg, прозапальні та протизапальні цитокіни, тиреоїдні автоантитіла.

АЗЩЗ є найбільш поширеним органоспецифічним автоімунним розладом і включає два основні клінічні прояви: ТХ (автоімунний тиреоїдит, хронічний лімфоцитарний тиреоїдит,

(อ) Т.Ф. Захарченко, В.І. Кравченко зоб Хашимото) і ХГ (дифузний токсичний зоб, Базедова хвороба, гіпертиреоз), клінічними ознаками яких є гіпотиреоз та тиреотоксикоз відповідно [1, 2]. Найпоширеніший позатиреоїдний прояв ХГ - ОГ - складний процес 
захворювання, який, як передбачається, виникає внаслідок автоімунного процесу, що розвивається в ЩЗ та м'яких тканинах орбіти ока.

ХГ і ТХ тісно пов'язані патофізіологічно, хоча і не функціонально, про що свідчить родинна асоціація ХГ і той факт, що ХГ іноді може перерости в ТX і навпаки. До складності діагностики може призводити наявність різного тиреоїдного стану на різних етапах АЗЩЗ. Більшість форм ТХ зрештою переростають у гіпотиреоз, хоча під час виявлення пацієнти можуть бути еутиреоїдними або навіть гіпертиреоїдними. Класична форма TX маніфестує зазвичай після 50 років життя і в більшості випадків зустрічається в жінок. Спостерігається збільшення розміру ЩЖ. На момент встановлення діагнозу 75\% пацієнтів знаходяться в стані еутиреозу, у решти пацієнтів спектр порушень функції ЩЗ варіює від субклінічного гіпотиреозу (підвищення рівня тиреотропного гормону (thyroid-stimulating hormone, TSH) при нормальних рівнях тиреоїдних гормонів) до явного гіпотиреозу. Хашітоксикоз - варіант, який має клінічну картину ХГ і патогістологічні ознаки ТХ. Від самого початку розвивається фаза гіпертиреозу, яка практично не відрізняється від ХГ і присутністю тиреоїдстимулювальних антитіл. Однак гіпертиреоз, як правило, транзиторний і переходить у незворотний гіпотиреоз [3].

На схильність до ХГ, ТХ і, як не дивно, до інших автоімунних захворювань (АIЗ) у значній мірі впливає поліморфізм імуномодулювальних генів. Високий ризик несуть гени схильності до АЗЩЗ, які класифікуються або як тиреоїдної специфічності (Tg, TSHR), або як імуномодулювальні (FOXP3, CD25, CD40, CTLA-4, HLA) з HLA-DR3. Гени схильності до АЗЩЗ - (Forkhead box protein 3) і CD25 ( $\alpha$-субодиниці рецептора IL-2) відіграють вирішальну роль у створенні периферичної толерантності, тоді як CD40, CTLA-4 (Cytotoxic T-lymphocyte-associated protein 4), а також гени лейкоцитарних антигенів людини (human leukocyte antigen, HLA) є ключовими для активації Т-лімфоцитів і презентації антигена [2].

Патогенез TX і ХГ розвивається багато в чому за схожими імунологічними механізмами, зокрема, супроводжується лімфоцитарною інфільтрацією ЩЗ і продукцією широкого спектра цитокінів. Разом із тим клінічні прояви цих патологій свідчать про реалізацію специфічних механізмів автореактивних процесів. Відмінності в експресії фенотипу ТХ та ХГ зумовлюються різним типом імунної відповіді, що спостерігається при цих двох клінічно протилежних тиреоїдних захворюваннях. Клінічний прояв автоімунного фенотипу в напрямку до ТХ або ХГ значною мірою залежить від балансу імунної відповіді, індукованої клітинами Т-хелперами ( $\mathrm{T}$ helper cells, Th) i антигенпрезентувальними клітинами (antigen-presenting cells, APCs), та цитокінового профілю, який домінує в цей момент у паренхімі Щ3.

Водночас, той факт, що ці два функціонально протилежні стани можуть розвиватися в однієї людини в різні періоди, говорить про те, що баланс Th1/Th2 і пов'язаний із цим цитокіновий профіль є динамічним процесом, який розвивається під впливом зовнішніх факторів, що діють у місцевому середовищі Щ3 [4]. Дослідження клітинних механізмів, що беруть участь у патогенезі АЗЩЗ, зосереджує увагу на ролі нещодавно охарактеризованих субпопуляцій Т-клітин - T регуляторних та Th17 лімфоцитів, а також В лімфоцитів, їх цитокінів і APCs [5].

Цей огляд має на меті узагальнити сучасні дані та досягнення у визначенні основних маркерів патогенезу, можливостей їх використання в діагностиці, прогнозуванні та терапії АЗЩЗ.

Діагностичне та прогностичне значення цитокінів при АЗЩЗ

У патогенезі АЗЩЗ в індуктивній та ефекторній фазі імунної відповіді та запалення ключову роль відіграють цитокіни. Цитокіни - білки, що регулюють міжклітинні і міжсистемні взаємодії, визначають виживаність клітин, стимуляцію або пригнічення їх росту, диференціацію, функціональну активність і апоптоз, а також забезпечують узгодженість дії імунної, ендокринної та нервової систем у нормальних умовах і у відповідь на патологічні впливи.

Розрізняють профіль цитокінів: інтерлейкіни (interleukins, IL), які зі свого боку поділяються на прозапальні (IL-1, IL-2, IL-6, IL-8, IL-18 та ін.) і протизапальні (IL-4, IL-10, IL-14 та ін.); інтерферони (interferon, IFN): IFN- $\alpha$, IFN- $\beta$ та IFN- $\gamma$ - із вираженою 


\section{Огляди}

противірусною дією; фактори некрозу пухлини (tumor necrosis factor, TNF): TNF- $\alpha$ i TNF- $\beta$ - цитокіни з цитотоксичною дією; регуляторні цитокіни (IL-10, трансформуючий фактор росту $\beta$ (transforming growth factor- $\beta$, TGF- $\beta$ )); хемокіни (IL-8 та IL-16) - хемоатрактанти для лейкоцитів; ростові фактори (TGF- $\beta$, інсуліноподібний фактор росту 1 (insulin-like growth factor $1, \mathrm{IGF}-1$ ) та IL-14) і деякі інші, проапоптоптичні та антиапоптотичні.

Під впливом антигенного стимулу макрофагів $\mathrm{CD}^{+}$Т-клітини, що продукують цитокіни, можуть розділятися або на Th1, які беруть участь у клітинній відповіді (IL-2, IFN- $\gamma$, TNF- $\alpha$ та IL-1 $\beta$ ), або на субпопуляції Th2, які виділяють цитокіни, пов'язані з гуморальною відповіддю (IL-4, IL-5, IL-6, IL-10 та IL-13), або на Th17, що продукують IL-17, IL-21, IL-22 та ін. Імунні Th3 (Treg) виробляють головним чином TGF- $\beta$ і відіграють важливу роль у захисті від виникнення АІЗ.

Визначення концентрації цитокінів у периферичній крові може дати інформацію про функціональну активність різних типів імуноцитів або епітеліальних клітин, тяжкості автоімунного запалення, перехід його на системний рівень і прогноз захворювання.

Цитокіни беруть участь у патогенезі АЗЩЗ, функціонуючи як в імунній системі, так і безпосередньо орієнтовані на тиреоїдні фолікулярні клітини. I клітини запалення, і фолікулярні клітини ЩЗ продукують численні цитокіни: IL-1 $\alpha$, IL-1 $\beta$, IL-2, IL-4, IL-6, IL-8, IL-10, IL-12, IL-13, IL-14, TNF- $\alpha$ та IFN- $\gamma$ [4]. Причому тиреоцити можуть бути джерелом опозитних цитокінів і активно взаємодіяти 3 інтратиреоїдними Т-лімфоцитами [6].

Диференціація $\mathrm{CD}^{+}$клітин у специфічних умовах імунних медіаторів (наприклад, цитокінів і хемокінів) призводить до утворення різних субпопуляцій Т-клітин. Змішана схема вироблення цитокінів Т-клітинами вказує на те, що обидві субпопуляції Т-хелперів (Th1 i Th2) беруть участь у всіх типах АЗЩЗ. Декілька В- і Т-клітинних шляхів активації через APC, особливо дендритних клітин, та продукцію цитокінів призводять до специфічної диференціації Th17 і Treg клітин, які також відіграють істотну роль у патогенезі АЗЩЗ [5]. Знижений вміст Treg може бути залучений до
ХГ, тоді як збільшення Th17 лімфоцитів може відігравати важливішу роль у патогенезі ОГ i TX [7].

На сьогодні IFN- $\gamma$ (здебільшого продукується Т-лімфоцитами, натуральними кілерними клітинами (natural killer cells, NK cells), ендотеліоцитами та іншими клітинами) розглядається багатьма авторами як основний цитокін, який бере участь у патогенезі АЗЩЗ. Виявлений підвищений інтратиреоїдний рівень IFN- $\gamma$ запропоновано використовувати як маркер-предиктор перебігу ТХ. У хворих на ХГ вірогідне підвищення рівнів IFN- $\gamma$ і IL-4 дає можливість використовувати ці маркери для діагностики і прогнозу перебігу захворювання [8, 6].

До патогенезу АIЗ (ТX, ХГ, ОГ, діабет 1-го типу та хвороба Аддісона) причетний хемокіновий рецептор тип 3 сімейства СXC (chemokine receptor type 3, CXCR3) та його ліганди CXCL9, CXCL10 і CXCL11, які є IFN- $\gamma$ залежними прозапальними хемокінами. У всіх вищезгаданих АIЗ показано високий рівень циркуляції хемокінів, особливо в ранні фази автоімунної відповіді. Фолікулярні клітини Щ3, ретроорбітальні клітини (фібробласти, преадипоцити та міобласти), $\beta$-клітини острівців Лангерганса i клітини надниркових залоз відповідають на стимуляцію IFN- $\gamma$ продукуванням великої кількості цих хемокінів, що послідовно стимулює вивільнення Th1 хемокінів, посилює цикл зворотного зв'язку, ініціює та продовжує автоімунний процес. При ХГ і ОГ високий рівень стимулювальних хемокінів IFN- $\gamma$ і TNF- $\alpha$ пов'язаний з «активною фазою» захворювання [1, 9]. 3 патогенезом АЗЩЗ пов'язана внутрішньотиреоїдна продукція IL-14 (ростовий фактор B-клітин) та IL-16 (хемокін). Фолікулярні тиреоїдні клітини проявляють здатність експресувати IL-14 та IL-16 мРНК [10].

Важливу роль в імунній відповіді багатьох захворювань відіграє хемокін IL-8, який продукується моноцитами/макрофагами, Т клітинами, поліморфноядерними нейтрофілами, NK-клітинами та ін. IL-8, у першу чергу, активує нейтрофіли та інші гранулоцитарні лейкоцити та моноцити, викликаючи їх хемотаксис у вогнище запалення. IL-8 є потужним прозапальним цитокіном, пов'язаним з АЗЩЗ, i може підвищити ступінь інфільтрації 
лімфоцитів всередині ЩЗ. У всіх пацієнтів із ХГ, ОГ і ТХ показано підвищений вміст IL-8 у сироватці крові [11]. Рівень експресії IL-8 був пов'язаний із розвитком ХГ, а частота однонуклеотидного поліморфізму С-алелей rs2227306 значно вища у хворих на ХГ та ОГ порівняно зі здоровими особами [12].

В останні роки продемонстровано, що IL-1 $\beta$ (здебільшого продукується моноцитами/макрофагами, NK-клітинами, В-лімфоцитами, поліморфноядерними нейтрофілами, дендритними та ендотеліальними клітинами, фібробластами тощо) є не тільки важливим патогенетичним чинником ТХ, а й одночасно специфічним маркером для діагностики цього захворювання. Крім того, виявлено істотні відмінності в інтратиреоїдному вмісті мРНК IЛ-1 $\beta$ при TX порівняно з ХГ, що може розглядатися в якості додаткового діагностичного критерію при АЗЩЗ [13]. При ХГ IL-1 $\beta$ стимулює вироблення гіалуронової кислоти в епітеліальних клітинах ЩЗ та фібробластах, тим самим сприяючи розвитку зоба. При OГ патогенна дія цитокінів (IL-1 $\beta$, TNF- $\alpha$ та IFN- $\gamma$ ) посилює запалення та проліферацію фібробластів, що призводить до накопичення в тканинах орбіти глікозаміногліканів [14].

IL-2, який продукується субпопуляцією Th1, Т-цитотоксичними лімфоцитами (T-cytotoxic lymphocytes, Tc) i NK-клітинами, грає одну з найважливіших ролей у патогенезі АЗЩЗ, впливаючи на Th1/Th2-клітинний баланс і на субпопуляцію Treg. Він чинить прямий і опосередкований вплив на інтратиреоїдну субпопуляцію Th і на цитотоксичні реакції клітин у тиреоїдному епітелії. Виявлено сильний позитивний зв'язок між сироватковими рівнями розчинного рецептора IL-2 (sIL-2R), IL-12 і IL-18 та їх підвищенням у гіпертиреоїдну стадію ХГ, що свідчить про важливу роль Th1-відповіді в патогенезі захворювання [15].

У нелікованих пацієнтів із ХГ та ТХ було показано підвищення концентрації IL-21 (гомолог IL-2, IL-4 та IL-15) у сироватці крові, який в основному продукується активованими Th17-клітинами. У периферичній крові пацієнтів із TX значно збільшився рівень IL-21( ${ }^{+}$) $\left.\mathrm{CD} 3\left(^{+}\right) \mathrm{CD}^{+}\right)$T-клітин порівняно зі здоровими добровольцями. Експресія мPНК IL-21 у мононуклеарах периферичної крові пацієнтів із ХГ та TX різко зростає і спостерігається помітне збільшення мРНК IL-21 та IL-21R у тиреоїдній тканині пацієнтв із ТХ [16].

IL-6 синтезується активованими макрофагами i Т-клітинами та стимулює імунну відповідь. IL-6 має важливе значення для диференціації Th17-клітин, оскільки він інгібує TGF- $\beta$-індукований розвиток Treg та відіграє значну роль у модуляції співвідношення Th17/Treg [17]. Наявність прозапальних цитокінів, таких як IL-6 i IL-21, може призвести до диференціації Th17-клітин і підвищення експресії рецептора IL-23R, що може бути використано для ідентифікації цієї субпопуляції клітин [18].

Для розвитку Th17 необхідний специфічний фактор транскрипції - ретиноїдний орфанний рецептор $\gamma \mathrm{t}$ (retinoid-related orphan receptor $\gamma \mathrm{t}$, ROR $\gamma \mathrm{t}$ ), який бере участь y патогенезі АIЗ. Дослідження значення осі IL-23/IL-17 у пацієнтів із ХГ показало, що експресія ROR $\gamma \mathrm{t}$, рівні мРНК IL-17 та IL-17 були помітно вищими в групі з ХГ порівняно 3 контрольною групою. Вісь IL-23/IL-17 асоціюється 3 патогенезом ХГ в її активному терміні та цей ефект не залежить від функції ЩЗ, але може бути пов'язаний з автоімунним процесом [18].

Разом із тим, в іншому дослідженні рівні мРНК IL-17A та IFN- $\gamma$ у мононуклеарах периферичної крові і в тиреоїдній тканині пацієнтів із ХГ суттєво не відрізнялися від контрольних, але збільшувалися в пацієнтів, які страждають на ТX [19], що потребує подальшого дослідження. У пацієнтів із ТХ виявлено порушення балансу між прозапальними (TNF- $\alpha$, IL-1 $\beta$ і IL-6) цитокінами і протизапальним цитокіном IL-4, що призводить до розвитку гіпертрофічних процесів у ЩЗ. У пацієнтів із вузловим зобом на тлі ТХ виявлено підвищення рівня TNF- $\alpha$ та IL-1 $\beta$ у сироватці крові порівняно 3 контролем та істотне зниження апоптичної активності лімфоцитів [20].

Значення функції регуляторних Т-клітин $\mathrm{CD}_{4}^{+}$, що експресують транскрипційний фактор FOXP3, у розвитку автоімунітету визначається основними пригнічувальними цитокінами TGF- $\beta$ та IL-10, які вони продукують. Цитокін TGF- $\beta$ є ключовим для підтримки імунологічної толерантності через вплив на диференціацію, проліферацію та виживання лімфоцитів та інших імуноцитів [21]. 
Огляди

У периферичній крові субпопуляція FOXP3 ${ }^{+}$Treg може порушуватися або в кількості, або в її пригнічувальній функції, або в обох показниках одночасно. Субпопуляція Treg клітин людини гетерогенна за фенотипом і функціями, що може пояснювати ці розбіжності. Так, у пацієнтів з АЗЩЗ і здорових осіб не було виявлено жодних відмінностей у кількості Treg у відсотках від $\mathrm{CD}_{4}^{+}$-клітин. Однак Treg були менш здатні пригнічувати проліферацію Т-ефекторних клітин (Th1, Th2, Th17) порівняно зі здоровими особами, що свідчить про їх дисфункціональність і що, можливо, пояснює їх участь в автоімунітеті. Отже, визначення функції Treg може допомогти в розкритті ролі цих регуляторів у патогенезі та може мати вагомий діагностичний потенціал при АЗЩЗ [22].

Значний вплив на прогресування АЗЩЗ має дисбаланс між Th17-лімфоцитами та Treg, що є дуже важливим у розвитку захворювання [23]. У дітей, які страждають на ТХ, спосте-

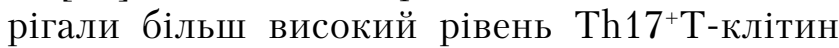
і низьке співвідношення Treg/Th17, що свідчить про можливу роль $\mathrm{Th} 17^{+}$Т-клітин у ініціації та розвитку імунних і запальних процесів у Щ3 [24]. Більше того, у пацієнтів із ТХ виявлено високий рівень Тh-17-асоційованих прозапальних цитокінів у сироватці крові [25]. У дітей із нелікованою ХГ у периферичній крові було виявлено статистично значущу позитивну кореляцію між відсотком Treg FохР3-клітин та рівнем антитіл до рецептора тиреоїдстимулювального гормону (antibodies to thyroid-stimulating hormone receptor, TR$\mathrm{Ab)}$ і позитивну кореляцію між відсотком Th17 (CD4 ${ }^{+}$CD-IL-17) і рівнем TS-Ab (TSHRstimulating antibodies, TS-Ab), що свідчить про залучення співвідношення Th17/Treg клітин до патогенеза цього захворювання [24].

Для гальмування імунної відповіді при АЗЩЗ Treg виділяють IL-10 та інші регуляторні цитокіни (TGF- $\beta$, IFN- $\gamma$ та IL-35), а також експресують на своїй поверхні рецептор-4, асоційований із цитотоксичними Т-лімфоцитами (cytotoxic T-lymphocyteassociated protein 4, CTLA-4). Основний ефект IL-10 полягає в зниженні синтезу цитокінів Th1-клітинами (тобто він володіє протилежною дією до IFN- $\gamma$ ) і в зниженні продукції прозапальних цитокінів макрофагами. Беручи участь у регуляції продукції Tg-Ab, IL-10 може пригнічувати клітинно-опосередковане пошкодження ЩЗ при ТХ.

Дослідження балансу між клітинами $\mathrm{CD} 4^{+} \mathrm{T}$, що продукують IL-17 (Th17) та клітинами $\mathrm{CD}^{+} \mathrm{T}$, що продукують IL-10 (Th10) показало, що після стимуляції тиреоїдними антигенами Tg і ТРО у пацієнтів із ТХ підвищувалось співвідношення Th17/Th10, що вказує на зміщення диференціації цих клітин до Th17. До того ж, пацієнти з ТХ виявили вищу, ніж здорові донори, вихідну продукцію IL-6 i TGF- $\beta 1$, які мають важливе значення для диференціації Тh17 та їх збільшення [25, 26].

Нещодавні дослідження визначили специфічну субпопуляцію В-клітин як регуляторну, яка здатна пригнічувати імунну відповідь, включаючи інгібування активації Т-клітин, індукцію Treg, експресію IL-10, IL-35 і TGF- $\beta$ та взаємодію рецептор-1/ліганд-1 програмованої загибелі клітин (programmed cell death protein-1/ligand-1, PD-1/PD-L1). Вreg сприяють підтримці периферичної толерантності та пригніченню імунної реакції на специфічні автоантигени, головним чином, продукуючи IL-10 i TGF- $\beta[27,28]$.

Причиною втрати імунної толерантності та розвитку автоімунного процесу в ЩЗ у нелікованих пацієнтів із ХГ та ТХ може бути значне зниження Breg лімфоцитів периферичної крові. Утім, при АЗЩЗ кількість та функція Breg i Treg остаточно не з'ясована. Для Breg ще не знайдено точного фенотипу і вони ідентифікуються за здатністю продукувати IL-10. Breg можуть визначатися такими фенотипами, як $\mathrm{CD}^{+}, \mathrm{CD} 25^{+}$, $\mathrm{TIM} 1^{+}$, CD24hiCD38hi та CD27 ${ }^{+} \mathrm{CD} 43^{+}$. У пацієнтів із АЗЩЗ субпопуляції клітин IL-10+B частіше експресували поверхневі маркери CD25 або Т-клітинного імуноглобуліна і домену-1 муцина ( $\mathrm{T}$ cell immunoglobulin and mucin domain-1, TIM-1), який необідний для костимуляції Breg та продукції IL-10 [25].

Існує твердження, що ХГ та ТХ не пов’язані зі зменшенням кількості клітин Breg, що продукують IL-10. До того ж, тиреоїдні антигени власної ЩЗ були здатні індукувати антигенспецифічну продукцію IL-10 у CD19+B-клітинах та CD $4^{+} \mathrm{T}$ клітинах серед здорових донорів та пацієнтів з ХГ або ТХ, що свідчить про відсутність порушення у виробленні IL-10, а отже, і порушення імунорегуляторної відповіді [25, 26]. 
На противагу цьому, інше дослідження виявило в дітей із ХГ або ТХ тенденцію до зменшення кількості Breg, що експресують CD $19{ }^{+} \mathrm{CD} 24^{+} \mathrm{CD} 27^{+} \mathrm{IL}-10^{+}$i $\mathrm{CD} 19^{+} \mathrm{IL}-10^{+}$, які можуть бути відповідальними за імунний дисбаланс [29]. Експериментальне культивування Т-клітин з автологічними В-лімфоцитами (CD24 ${ }^{+} \mathrm{CD} 38^{+} \mathrm{B}$-клітини) пацієнтів із TX показало знижену здатність останніх пригнічувати проліферацію Т-клітин, а також продукувати TNF та IFN- $\gamma$, що було пов'язано $з$ нестачею IL-10 [30].

Результати дослідження Breg, що продукують IL-10, у пацієнтів із тиреоїдасоційованою офтальмопатією встановили, що при стимуляції лігандом CD40L і цитозин-фосфат-гуанозином (cytosine-phosphate-guanosine, $\mathrm{CpG}$ ) інкубованих мононуклеарних клітин периферичної крові цих пацієнтів відбувалось зменшення частоти клітин IL-10+3 порівняно зі здоровим контролем [31]. У пацієнтів із тиреоїдасоційованою офтальмопатією функція Breg була порушена, хоча вони мали вищу частоту експресії IL-10, що продукують Breg, та експресію IL-10 у відповідь на стимуляцію TSH, ніж пацієнти без стимуляції TSH і здорові особи. Зроблено висновок, що функціонально неповноцінні Breg можуть бути відповідальними за патогенез тиреоїдасоційованої офтальмопатії [32].

IL-37, як представник сімейства IL-1, є природним інгібітором імунних і запальних реакцій, який протидіє оксидативному стресу та запаленню. При АЗЩЗ, включаючи ХГ та ТХ, спостерігається підвищення рівня сироваткового IL-37 [33].

TGF- $\beta$, як головний регулятор імунної відповіді, залучений у розвиток АЗЩЗ і тісно асоціює з їх тяжкістю [28].

Діагностичне та прогностичне значення тиреоїдних автоантитіл

Незважаючи на велику кількість гіпотез імунопатогенезу АЗЩЗ, вірогідно встановлено, що початковим етапом розвитку ХГ, ОГ і ТХ є втрата імунологічної толерантності до автоантигенів ЩЗ, а завершальним - вироблення автоантитіл до них. Антитиреоїдні антитіла спрямовані проти одного або декількох антигенів ЩЗ. Найбільш клінічно значущими антитиреоїдними антитілами є різні за патофізіологічною роллю антитіла до тиреоїдної пероксидази (autoantibodies to thyroid peroxidase, TPO-Ab), антитіла до рецептора тиреотропного гормону (autoantibodies to TSH receptor, TR-Ab) та антитіла до тиреоглобуліну (autoantibodies to thyroglobulin, Tg-Ab). Останнім відкриттям є антитіла до натрій йод симпортеру (autoantibodies to sodium-iodide symporter, NIS-Ab), які присутні приблизно у 20\% випадків ХГ та 24\% випадків ТХ [34].

TR-Ab є клініко-лабораторним маркером ХГ і досліджуються при диференціальній діагностиці синдрому гіпертиреозу. Наявність TR-Ab не характерно для інших причин гіпертиреозу, таких як токсичний вузловий зоб, гранулематозний тиреоїдит або введення екзогенного тироксину. Стимулюючі TR-Ab виявляються у 85-100\% пацієнтів із ХГ і можуть служити його діагностичним критерієм. Концентрація TR-Ab відображає активність захворювання [35]. Також TR-Ab не є визначальними для йодіндукованого тиреотоксикозу та TX у гіпертиреоїдну фазу. TR-Ab - це гетерогенна група автоантитіл, що взаємодіють із TSHR Щ3 і поділяються на стимулюючі (TSHR-stimulating antibodies, TS-Ab) та блокуючі (TSHR-blocking antibodies, TB-Ab) антитіла залежно від їх впливу на TSHR. TSAb значно підсилюють функцію ЩЗ, що спричиняє розвиток дифузного зобу і гіпертиреозу. TBAb перешкоджають дії TSH і призводять до атрофії ЩЗ і гіпотиреозу.

$\mathrm{y}$ крові одного й того ж пацієнта одночасно можуть бути виявлені обидва варіанти антитіл (TS-Ab і TB-Ab). Вони є безпосередньою причиною ХГ і ТХ, який розвивається пізніше. У 15-20\% пацієнтів із ХГ може виникати спонтанний гіпотиреоз внаслідок хронічного тиреоїдиту - ТХ [36]. Причиною виникнення хронічного тиреоїдиту або ТХ після епізоду ХГ може бути розширення імунної відповіді імунна відповідь на ТPO та Tg, які можуть посилити інфільтрацію лімфоцитів і нарешті викликати ТХ [37].

При ХГ втрата імунної толерантності до TSHR та генерація TS-Ab є центральними та специфічними для захворювання подіями в розвитку ХГ. На відміну від процесу, що відбувається в ЩЗ при ХГ, роль TSHR та TS-Ab у патогенезі ОГ значно менш чітко визначена. Особливого значення надається IGF-IR на орбітальних фібробластах. Докази того, що 
ці автоантитіла та TSHR беруть участь безпосередньо чи опосередковано, є значними, але здебільшого непрямими. TS-Ab можуть бути виявлені в більшості пацієнтів з ОГ, однак ці антитіла також можна виявити в більшості пацієнтів із ХГ та гіпертиреозом, але в яких клінічно значуща ОГ не розвивається [38].

Фермент ТРО грає ключову роль у синтезі тиреоїдних гормонів: він бере участь в утворенні активної молекулярної форми йоду, без якої неможливий біохімічний синтез гормонів Щ3 - тироксину (thyroxine, $\mathrm{T}_{4}$ ) і трийодтироніну (triiodothyronine, $\mathrm{T}_{3}$ ). Поява в крові антитіл до цього ферменту порушує його нормальну функцію, внаслідок чого знижується синтез відповідних гормонів [39].

Проведення комплексного аналізу рівня автоантитіл для диференційної діагностики між ХГ та ТХ показало, що в групі з ХГ позитивні показники для TR-Ab, TPO-Ab i Tg-Ab склали 83,67\%, 75,51\% і 48,98\% відповідно. У групі TX позитивний показник TR-Ab склав 13,64\%, a позитивний показник для решти автоантитіл - 86,36\%. Подвійний позитивний показник TPO-Ab i Tg-Ab становив 86,36\% у групі TX, що значно вище, ніж у групі ХГ - 48,98\% [40].

$\mathrm{TPO}-\mathrm{Ab}$ - це найпоширеніші тиреоїдні автоантитіла, присутні приблизно в 90\% пацієнтів із ТХ, 75\% пацієнтів із ХГ і 10-20\% пацієнтів із вузловим зобом. Також 10-15\% нормальних людей можуть мати високі титри TPO-Ab. Високий рівень сироваткових ТРО$\mathrm{Ab}$ виявляється при хронічному ТХ в активній фазі. Титр ТРО-Аb у сироватці пацієнтів можна використовувати для оцінки активності захворювання [41].

Більшість ТРО-Аb продукуються В-лімфоцитами, що інфільтрують Щ3, із незначним внеском лімфатичних вузлів і кісткового мозку. Титр ТРО-Аb значно корелює з вираженістю інфільтрації тиреоїдної тканини автореактивними лімфоцитами. Tg-Ab i TPO-Ab відображають дві незалежні автоімунні відповіді до тиреоїдної тканини. Поява Tg-Ab може відображати первинну (вроджену) імунну відповідь, тоді як поява ТРО-Аb може бути відображенням вторинної (набутої) імунної відповіді, тобто її посилення. Відповідно до цієї гіпотези, Tg-Ab повинні виявлятися на початкових стадіях захворювання. Характер перебігу АЗЩЗ робить практично неможливим їх виявлення на ранніх стадіях. При ТХ час від початку захворювання до встановлення діагнозу становить у середньому не менше 7 років. Тому в пацієнтів із TX TPO-Аb виявляються частіше і в більш високих титрах, ніж Tg$\mathrm{Ab}[3]$.

TPO-Ab опосередковано можуть спричинити пошкодження клітин ЩЗ шляхом антитіло-залежної цитотоксичності клітин (antibody-dependent cell-mediated cytotoxicity, ADCC) [42]. Утім механізми цього процесу остаточно не з'ясовано. Немає переконливих доказів, що TPO-Ab за участі активації комплементу сприяють руйнуванню клітин ЩЗ. Діагноз ТХ виставляється при виявленні циркулюючих антитіл до тиреоїдних антигенів (переважно ТPO-Ab i Tg-Ab). Концентрація TPO-Ab i Tg-Ab в осіб, що мають обидва типи автоантитіл, значно вищі, ніж у тих, у кого виявлено лише один тип автоантитіл [39].

$\mathrm{Tg}-\mathrm{Ab}$ - імуноглобуліни, спрямовані проти попередника тиреоїдних гормонів. Вони є специфічним маркером АЗЩЗ (ТХ, ХГ і ОГ). При секреції гормонів Tg у незначній кількості потрапляє в кров. За невідомих причин він може ставати автоантигеном, у зв'язку з чим у відповідь організм виробляє до нього антитіла, що викликає запалення ЩЗ. Tg-Ab можуть блокувати $\mathrm{Tg}$, порушуючи при цьому нормальний синтез тиреоїдних гормонів і викликаючи гіпотиреоз, або, навпаки, надмірно стимулювати залозу, викликаючи її гіперфункцію.

Автоімунна реакція є причиною змін із боку тканин ока при тиреотоксичній офтальмопатії. Tg-Ab одночасно взаємодіють із компонентами сполучної тканини ока, очних м'язів і ферментом ацетилхолінестеразою. Tg-Ab виявляють у 40-70\% пацієнтів із хронічним ТХ, у 70\% пацієнтів із гіпотиреозом, у 40\% пацієнтів із ХГ і у невеликої кількості пацієнтів з іншими автоімунними патологіями - перніціозна анемія, автоімунна гемолітична анемія, системний червоний вовчак, хвороба Шегрена, ревматоїдний артрит, міастенія та цукровий діабет 1-го типу [1, 34].

\section{Висновки}

1. При ХГ втрата імунної толерантності до TSHR та генерація TS-Ab є центральними та специфічними подіями в розвитку 
захворювання. Визначення концентрацій $\mathrm{TR}-\mathrm{Ab}$ допомагає при диференційній діагностиці гіпертиреозу та ХГ, етіології та прогнозуванні рецидиву після лікування антитиреоїдними препаратами. У патогенезі ОГ особливого значення надається IGF-IR на орбітальних фібробластах. Титр ТРО-Ab значно корелює з вираженістю інфільтрації тиреоїдної тканини автореактивними лімфоцитами. Високий рівень сироваткових TPO-Ab свідчить про активну фазу хронічного TX.

2. Істотні відмінності в інтратиреоїдному вмісті мРНК ІЛ-1 $\beta$ при ТХ порівняно з ХГ може розглядатися в якості додаткового діагностичного критерію. Циркулюючі рівні IFN- $\gamma$ і TNF- $\alpha$, співвідношення IL-23/IL-17 пов'язані з активною фазою ХГ.

3. Збільшення Th17 лімфоцитів та цитокінів, які вони синтезують (IL-17, IL-21 та IL-22), може відігравати важливішу роль у патогенезі ТХ, тоді як знижені вміст Treg та/або продукція цитокінів IL-10, IL-35 і TGF- $\beta$ цими регуляторними клітинами можуть мати більше значення в патогенезі ХГ та ОГ.

4. Визначення функції Treg i Breg, які продукують IL-10, допоможе в розкритті ролі цих клітин в автоімунітеті та може мати значний діагностичний та терапевтичний потенціал при АЗЩЗ. Як головний регулятор імунної відповіді TGF- $\beta$ бере участь у розвитку АЗЩЗ і може мати вагоме значення для діагностики, прогнозу та терапії цих захворювань.

\section{Список використаної літератури}

1. Antonelli A, Ferrari SM, Corrado A, Di Domenicantonio A, Fallahi P. Autoimmune thyroid disorders. Autoimmun Rev. 2015 Feb;14(2):174-80. doi: 10.1016/j.autrev.2014.10.016.

2. Lee HJ, Li CW, Hammerstad SS, Stefan M, Tomer Y. Immunogenetics of autoimmune thyroid diseases: A comprehensive review. J Autoimmun. 2015 Nov;64:82-90. doi: 10.1016/j. jaut.2015.07.009.

3. Caturegli P, De Remigis A, Rose NR. Hashimoto thyroiditis: clinical and diagnostic criteria. Autoimmun Rev. 2014 AprMay;13(4-5):391-7. doi: 10.1016/j.autrev.2014.01.007.

4. Mikoś H, Mikoś M, Obara-Moszyńska M, Niedziela M. The role of the immune system and cytokines involved in the pathogenesis of autoimmune thyroid disease (AITD). Endokrynol Pol. 2014;65(2):150-5. doi: 10.5603/EP.2014.0021.

5. Ramos-Leví AM, Marazuela M. Pathogenesis of thyroid autoimmune disease: the role of cellular mechanisms. Endocrinol Nutr. 2016 Oct;63(8):421-9. English, Spanish. doi: 10.1016/j. endonu.2016.04.003.

6. Bossowski A, Harasymczuk J, Moniuszko A, Bossowska A, Hilczer M, Ratomski K. Cytometric evaluation of intracellular
IFN- $\gamma$ and IL-4 levels in thyroid follicular cells from patients with autoimmune thyroid diseases. Thyroid Res. 2011 Sep 23;4:13. doi: 10.1186/1756-6614-4-13.

7. Li C, Yuan J, Zhu YF, Yang XJ, Wang Q, Xu J, et al. Imbalance of Th17/Treg in different subtypes of autoimmune thyroid diseases. Cell Physiol Biochem. 2016;40(1-2):245-252. doi: $10.1159 / 000452541$.

8. Alnaqdy A., Al-Maskari M. Levels of cytokines and thyroid autoantibodies in Omani patients with Graves' disease. Br J Biomed Sci. 2007;64(4):164-7. doi: 10.1080/09674845.2007.11732781.

9. Fallahi P, Ferrari SM, Ragusa F, Ruffilli I, Elia G, Paparo SR, et al. Th1 chemokines in putoimmune endocrine disorders. J Clin Endocrinol Metab. 2020 Apr 1;105(4): dgz289. doi: 10.1210/ clinem/dgz289.

10. Kemp EH, Ajjan RA, Metcalfe RA, Watson PF, Weetman AP IL-14 and IL-16 are expressed in the thyroid of patients with either Graves' disease or Hashimoto's thyroiditis. Clin Endocrinol (Oxf) 2015 Nov;83(5):726-32. doi: 10.1111/cen.12810.

11. Senturk T, Kozaci LD, Kok F, Kadikoylu G, Bolaman Z. Proinflammatory cytokine levels in hyperthyroidism. Clin Invest Med 2003;26(2):58-63.

12. Gu LQ, Jia HY, Zhao YJ, Liu N, Wang S, Cui B, et al. Association studies of interleukin-8 gene in Graves' disease and Graves' ophthalmopathy. Endocrine. 2009 Dec;36(3):452-6. doi: 10.1007/ s12020-009-9240-9.

13. Sun L, Zhang X, Dai F, Shen J, Ren C, Zuo C, et al. Elevated interleukin-1 $\beta$ in peripheral blood mononuclear cells contributes to the pathogenesis of autoimmune thyroid diseases, especially of Hashimoto thyroiditis. Endocr Res. 2016 Aug;41(3):185-92. doi: 10.3109/07435800.2015.1124439

14. Gianoukakis AG, Khadavi N, Smith TJ. Cytokines, Graves' disease, and thyroid-associated ophthalmopathy. Thyroid 2008;18: 953-8. doi: $10.1089 /$ thy.2007.0405.

15. Rapoport B, Mclachlan S.M. Graves' hyperthyroidism is antibodymediated but is predominantly a Th1-type cytokine disease. J Clin Endocrinol Metab. 2014 Nov;99(11):4060-1. doi: 10.1210/jc.2014-3011.

16. Guan LJ, Wang X, Meng S, Shi LF, Jiang WJ, Xiao L, et al. Increased IL-21/IL-21R expression and its proinflammatory effects in autoimmune thyroid disease. Cytokine. 2015 Apr;72(2):160-5. doi: 10.1016/j.cyto.2014.11.005.

17. Fasching P, Stradner M, Graninger W, Dejaco C, Fessler J Therapeutic potential of targeting the Th17/Treg axis in autoimmune disorders. Molecules. 2017 Jan 14;22(1):134. doi: 10.3390 /molecules22010134.

18. Zheng L, Ye P, Liu C. The role of the IL-23/IL-17 axis in the pathogenesis of Graves' disease. Endocr J. 2013;60(5):591-7. doi: 10.1507/endocrj.ej12-0264.

19. Qin Q, Liu P, Liu L, Wang R, Yan N, Yang J, et al. The increased but non-predominant expression of Th17- and Th1-specific cytokines in Hashimoto's thyroiditis but not in Graves' disease. Braz J Med Biol Res. 2012 Dec;45(12):1202-8. doi: 10.1590/s0100879x2012007500168.

20. Шеремет МІ, Гирла ЯВ, Ткачук НП, Козак ВП. Рівень цитокінів у сироватці крові хворих на автоімунний тиреоїдит у залежності від ступеня збільшення щитоподібної залози. Клінічна та експериментальна патологія. 2015;14(4):175-7 (Sheremet MI, Girla YaV, Tkachuk NP, Kozak VP. The level of cytokines in the blood serum of patients suffering from autoimmune thyroiditis depending on the degree of the thyroid gland enlargement. Clinical and experimental pathology. 2015;14(4):175-7). Ukrainian.

21. Mohr A, Atif M, Balderas R, Gorochov G, Miyara M. The role of FOXP3+regulatory $\mathrm{T}$ cells in human autoimmune and inflammatory diseases. Clin Exp Immunol. 2019 Jul;197(1):24-35. doi: $10.1111 /$ cei.13288.

22. Glick AB, Wodzinski A, Fu P, Levine AD, Wald DN. Impairment of regulatory $\mathrm{T}$-cell function in autoimmune thyroid disease. Thyroid. 2013 Jul;23(7):871-8. doi: 10.1089/thy.2012.0514.

23. Liu Y, Tang X, Tian J. Zhu C, Peng H, Rui K, et al. Th17/Treg cells imbalance and GITRL profile in patients with Hashimoto's thyroiditis. Int J Mol Sci. 2014;15:21674-86. doi: 10.3390/ ijms151221674.

24. Bossowski A, Moniuszko M, Idźkowska E, Grubczak K, Singh P, Bossowska A, et al. Decreased proportions of CD4 + IL17+/ $\mathrm{CD} 4+\mathrm{CD} 25+\mathrm{CD} 127-$ and $\mathrm{CD} 4+\mathrm{IL} 17+/ \mathrm{CD} 4+\mathrm{CD} 25$ 
Огляди

+ CD127 - FoxP3+ $\mathrm{T}$ cells in children with autoimmune thyroid diseases (.). Autoimmunity. 2016 Aug;49(5):320-8. doi: 10.1080/08916934.2016.1183654.

25. Kristensen B, Hegedüs L, Madsen HO, Smith TJ, Nielsen CH. Altered balance between self-reactive $\mathrm{T}$ helper (Th)17 cells and Th10 cells and between full-length forkhead box protein 3 (FoxP3) and FoxP3 splice variants in Hashimoto's thyroiditis. Clin Exp Immunol. 2015 Apr;180(1):58-69. doi: 10.1111/cei.12557.

26. Kristensen B. Regulatory B and T cell responses in patients with autoimmune thyroid disease and healthy controls. Dan Med J. 2016 Feb;63(2): B5177.

27. Maravillas-Montero JL, Acevedo-Ochoa E. Human B regulatory cells: the new players in autoimmune disease. Rev Investig Clin. 2017;69:243-246. doi: 10.24875/ric.17002266.

28. Kardalas E, Maraka S, Papagianni M, Paltoglou G, Siristatidis C, Mastorakos G. TGF- $\beta$ physiology as a novel therapeutic target regarding autoimmune thyroid diseases: where do we stand and what to expect. Medicina (Kaunas). 2021 Jun 14;57(6):621. doi: 10.3390 /medicina57060621

29. Stozek K, Grubczak K, Marolda V, Eljaszewicz A, Moniuszko M, Bossowski A. Lower proportion of CD19(+)IL-10(+) and CD19(+)CD24(+)CD27(+) but not CD1d $(+) \operatorname{CD} 5(+)$ CD19(+)CD24(+)CD27(+) IL-10(+) B cells in children with autoimmune thyroid diseases. Autoimmunity. 2020;53:46-55. doi: 10.1080/08916934.2019.1697690.

30. Yu S, Qi Y, Wang H, Jiang J, Sun L, Zhou Q. Dysfunction of CD24+CD38+ B cells in patients with Hashimoto's thyroiditis is associated with a lack of interleukin 10. Int J Biochem Cell Biol. 2017 Sep;90:114-120. doi: 10.1016/j.biocel.2017.08.002.

31. Ding YG, Chen G, Li Q, Wen XF, Wei L, Yang HS. Frequency of IL-10-producing regulatory B cells associated with disease activity in thyroid-associated orbitopathy. Int J Ophthalmol. 2018 Sep 18;11(9):1458-62. doi: 10.18240/ijo.2018.09.05.

32. Chen G, Ding Y, Li Q, Li Y, Wen X, Ji X, et al. Defective regulatory $B$ cells are associated with thyroid associated ophthalmopathy J Clin Endocrinol Metab. 2019 Sep;104(9):4067-77. doi: 10.1210/ jc.2018-01812.

33. Ruggeri RM, Cristani M, Vicchio TM, Alibrandi A, Giovinazzo S, Saija A, et al. Increased serum interleukin-37 (IL-37) levels correlate with oxidative stress parameters in Hashimoto's thyroiditis. J Endocrinol Invest. 2019 Feb;42(2):199-205. doi: 10.1007/s40618-018-0903-3.

34. Saravanan P, Dayan CM. Thyroid autoantibodies. Endocrinol Metab Clin North Am. 2001 Jun;30(2):315-37, viii. doi: 10.1016/ s0889-8529(05)70189-4.

35. Kamath C, Adlan MA, Premawardhana LD. The role of thyrotrophin receptor antibody assays in graves' disease. J Thyroid Res. 2012;2012:525936. doi: 10.1155/2012/525936.

36. Menconi F, Marcocci C, Marinò M. Diagnosis and classification of graves'disease. Autoimmun Rev. 2014 Apr-May;13(4-5):398-402 doi: 10.1016/j.autrev.2014.01.013.

37. Umar H, Muallima N, Adam JM, Sanusi H. Hashimoto's thyroiditis following Graves' disease. Acta Med Indones. 2010 Jan;42(1):31-5.

38. Smith TJ, Janssen JAMJL. Insulin-like growth factor-I receptor and thyroid-associated ophthalmopathy. Endocr Rev. 2019 Feb 1;40(1):236-67. doi: 10.1210/er.2018-00066.

39. Yan YR, Gao XL, Zeng J, Liu Y, Lv QG, Jiang J, et al. The association between thyroid autoantibodies in serum and abnormal function and structure of the thyroid. J Int Med Res. 2015 Jun;43(3):41223. doi: $10.1177 / 0300060514562487$

40. Hu YM, Liu W, Lu GH. [Significance of combining tests of thyroid autoantibodies in differential diagnosis between Graves's disease and Hashimoto's hyperthyroidism]. Zhonghua Yi Xue Za Zhi. 2003 Jun 10;83(11):940-2. Chinese.

41. Marcocci C, Marino M. Thyroid-directed antibodies. In: Braverman LE, Utiger RD, eds. Werner \& Ingbar's the thyroid: a fundamental and clinical text. Philadelphia: Lippincott, Williams \& Wilkins. 2005;360-72.

42. Ząbczyńska M, Polak K, Kozłowska K, Sokołowski G, Pocheć E. The contribution of IgG glycosylation to antibody-dependent cellmediated cytotoxicity (ADCC) and complement-dependent cytotoxicity (CDC) in Hashimoto's thyroiditis: an in vitro model of thyroid autoimmunity. Biomolecules. 2020 Jan 22;10(2):171. doi: $10.3390 /$ biom10020171.

\section{Autoimmune thyroid diseases and main markers of their pathogenesis and diagnosis}

\section{T.F. Zakharchenko, V.I. Kravchenko}

SI «V.P. Komisarenko Institute of Endocrinology and Metabolism of the National Academy of Medical Sciences of Ukraine»

Abstract. The presented review is devoted to evaluation of the main humoral factors in the pathogenesis of autoimmune thyroid diseases (AITD) and the possibility of their use in diagnosis and prognosis. It has been shown that clinically different Hashimoto's thyroiditis (HT), and Graves' disease (GD), Graves' ophthalmopathy (GO) are closely related pathophysiologically and have similar immune-mediated mechanisms - the production of autoantibodies to thyroid antigens and lymphocytic infiltration of the thyroid parenchyma. Loss of immune tolerance to thyroid peroxidase (TPO), thyroglobulin (Tg) and thyroid-stimulating hormone receptor (TSHR) autoantigens is the basis for the development of AITD. The role of pro-inflammatory and anti-inflammatory cytokines produced by immune system cells and thyrocytes is emphasized. Cytokines are involved in the inductive and effector phases of the immune response and inflammation, playing a key role in the pathogenesis of AITD. An imbalance between Th17 lymphocytes, which support the autoimmune response, and regulatory T cells (Treg), which suppress the autoimmune process, has a significant effect on the development and progression of AITD. Insufficiency of regulatory $B$ cells (Breg) and Treg, which produce anti-inflammatory cytokines, impairs immunological tolerance and causes abnormal production of proinflammatory cytokines, plays a part role in the pathogenesis of AITD. Detection of immune cells and antithyroid antibodies in thyroid tissue and determination of serum levels of pro-inflammatory and anti-inflammatory cytokines may provide an information on their involvement in the pathogenesis of AITD and may serve as markers of disease activity. The diagnostic value of the level of cytokines, thyroid autoantibodies in HT, GD, GO and their ability to reflect the presence and activity of the disease are considered.

Keywords: autoimmune thyroid diseases, Hashimoto's thyroiditis, Graves' disease, Graves' ophthalmopathy, Th17-lymphocytes, Treg, Breg, pro-inflammatory and anti-inflammatory cytokines, thyroid autoantibodies.

\section{Аутоиммунные заболевания щитовидной железы и главные маркеры их патогенеза и диагностики}

\section{Т.Ф. Захарченко, В.И. Кравченко}

ГУ «Институт эндокринологии и обмена веществ им. В.П. Комиссаренко НАМН Украины»

Резюме. Представленный обзор посвящен оценке основных гуморальных факторов в патогенезе аутоиммунных заболеваний щитовидной железы (АЗЩЖ) и возможности их использования в диа- 
гностике и прогнозировании. Показано, что клинически разные тиреоидит Хашимото (ТХ), болезнь Грейвса (БГ) и офтальмопатия Грейвса (ОГ) тесно связаны патофизиологически и имеют подобные иммуноопосредованные механизмы - продукция аутоантител к тиреоидным антигенам и лимфоидная инфильтрация тиреоидной паренхимы. Потеря иммунной толерантности к аутоантигенам тиреоидной пероксидазе (thyroid peroxidase, ТPO), тиреоглобулину (thyroglobulin, Tg) и рецептору тиреотропного гормона (thyroidstimulating hormone receptor, TSHR) является основой развития АЗЩЖ. Отмечается роль провоспалительных и противовоспалительных цитокинов, продуцируемых клетками иммунной системы и тиреоцитами. Значительное влияние на развитие и прогрессирование АЗЩЖ имеет дисбаланс между Тh17-лимфоцитами, которые поддерживают аутоиммунный ответ, и регуляторными Т-клетками (regulatory T cells, Treg), которые подавляют аутоиммунный процесс. Недостаточность регуляторных В-клеток (regulatory B cells, Breg) и Treg, которые вырабатывают противовоспалительные цитокины, нарушает иммунологическую толерантность и вызывает аномальную продукцию провоспалительных цитокинов, играет определенную роль в патогенезе АЗЩЖ. Обнаружение иммунных клеток и антитиреоидных антител в ткани щитовидной железы и определение уровней провоспалительных и противовоспалительных цитокинов в сыворотке крови могут дать информацию об их участии в патогенезе АЗЩЖ и могут служить маркерами активности заболевания. Рассмотрено диагностическое значение уровня цитокинов, тиреоидных аутоантител при ТХ, БГ, ОГ и их способность отражать наличие и активность заболевания.

Ключевые слова: аутоиммунные заболевания щитовидной железы, тиреоидит Хашимото, болезнь Грейвса, офтальмопатия Грейвса, Th17-лимфоциты, Treg, Breg, провоспалительные и противовоспалительные цитокины, тиреоидные аутоантитела.

Для цитування: Захарченко ТФ, Кравченко ВІ. Автоімунні захворювання щитоподібної залози та основні маркери їх патогенезу і діагностики. Ендокринологія. 2021;26(4):366-375. DOI: 10.31793/1680-1466.2021.26-4.366

Адреса для листування: Захарченко Тамара Федорівна, Ду «нститут ендокринології та обміну речовин ім. В.П. Комісаренка НАМН України», вул. Вишгородська, 69, Київ, 04114, Україна, E-mail: zatam@ukr.net.

Відомості про авторів: Захарченко Тамара Федорівна - канд. біол. наук, старш. наук. співроб. відділу епідеміології ендокринних захворювань, ORCID: 0000-0002-4394-8833; Кравченко Віктор Іванович, д-р мед. наук, проф., завідувач відділу епідеміології ендокринних захворювань, ORCID: 0000-0003-0867-2023.

Особистий внесок: Захарченко Т.Ф. - аналіз літературних джерел і написання тексту; Кравченко В.І. - ідея роботи й консультація під час редагування статті.

Фінансування: стаття підготовлена в рамках бюджетного фінансування НАМН України за планом науково-дослідних робіт ду «Інститут ендокринології та обміну речовин ім. В.П. Комісаренка НАМН України».
Декларація з етики: автори задекларували відсутність конфлікту інтересів і фінансових зобов'язань.

Стаття: надійшла до редакції 28.09.2021 р.; перероблена 09.11.2021 р.; прийнята до друку 15.12.2021 р.; надрукована 28.12.2021 p.

For citation: Zakharchenko TF, Kravchenko VI. Autoimmune thyroid diseases and main markers of their pathogenesis and diagnosis. Endokrynologia. 2021;26(4):366-375. DOl: 10.31793/16801466.2021.26-4.366.

Correspondence address: Zakharchenko Tamara, zatam@ukr.net, State Institution «V.P. Komisarenko Institute of Endocrinology and Metabolism of the National Academy of Medical Sciences of Ukraine», Vyshgorodska Str., 69, Kyiv 04114, Ukraine.

Information about the authors: Zakharchenko Tamara Fedorivna, Cand. Sci. (Biology), Department of Epidemiology of Endocrine Diseases, ORCID: 0000-0002-4394-8833; Kravchenko Viktor Ivanovych, Dr. Sci. (Medicine), Prof., Head of Department of Epidemiology of Endocrine Diseases, ORCID: 0000-0003-0867-2023.

Personal contribution: Zakharchenko T.F. - analysis of literary sources and text writing; Kravchenko V.I. - - idea of work and consultations when editing an article.

Funding: The article was prepared within the framework of budgetary funding of the National Academy of Medical Sciences of Ukraine according to the plan of research work of the State Institution «V.P. Komisarenko Institute of Endocrinology and Metabolism of the National Academy of Medical Sciences of Ukraine».

Declaration of Ethics: The authors have declared no conflicts of interest or financial obligations.

Article: received 28 September 2021; revised 09 November 2021; accepted 15 December 2021; published 28 December 2021.

Для цитирования: Захарченко ТФ, Кравченко ВИ. Аутоиммунные заболевания щитовидной железы и главные маркеры их патогенеза и диагностики. Эндокринология. 2021;26(4):366-375. DOI: 10.31793/1680-1466.2021.26-4.366.

Адрес для переписки: Захарченко Тамара Федоровна, E-mail: zatam@ukr.net, ГУ «Институт эндокринологии и обмена веществ им. В.П. Комиссаренко НАМН Украины», ул. Вышгородская, 69, Киев 04114, Украина.

Сведения об авторах: Захарченко Тамара Федоровна канд. биол. наук, старш. науч. сотруд. отдела эпидемиологии эндокринных заболеваний, ORCID: 0000-0002-4394-8833; Кравченко Виктор Иванович - д-р мед. наук, проф., заведующий отделом эпидемиологии эндокринных заболеваний, ORCID: 0000-00030867-2023.

Личный вклад: Захарченко Т.Ф. - анализ литературных источников и написание текста; Кравченко В.И. - идея работы и консультация при редактировании статьи

Финансирование: статья подготовлена в рамках бюджетного финансирования НАМН Украины по плану научно-исследовательских работ ГУ «Институт эндокринологии и обмена веществ им. В.П. Комиссаренко НАМН Украины».

Декларация по этике: авторы задекларировали отсутствие конфликта интересов и финансовых обязательств.

Статья: поступила в редакцию 28.09.2021 г;; переработана 09.11.2021 г.; принята в печать 15.12.2021 г.; напечатана 28.12.2021 г. 